\title{
Using Educational Information Network on the Education Process in Preschool Education
}

\author{
Sevilay SARIŞIK' ${ }^{1}$, Salih SARIŞIK², Müfide ÇALIK ${ }^{3}$
}

\begin{tabular}{l} 
ARTICLE INFO \\
\hline Article History \\
\\
Received11.11.2020 \\
Received in revised \\
form05.08.2021 \\
Available \\
online01.07.2022
\end{tabular}

\section{ARTICLE INFO}

online01.07.2022

\begin{abstract}
The aim of this study is to examine the effect of using Education Informatics Network in preschool education on the educational process according to the opinions of preschool teachers. Case study which is one of the qualitative research methods, was used in the study. The study group of the research consists of 19 preschool teachers working in pre-school education institutions affiliated to the Ministry of National Education in Sapanca district of Sakarya province in the academic year of 2019-2020. Semi-structured interview technique, one of the qualitative research methods, was used in the study. In the research, as a data collection tool, "semi-structured interview form" developed by the researcher was used In order to determine whether the questions in the interview form were suitable for the purpose of the interview or not, expert opinion was consulted. Necessary corrections were made in line with the suggestions and criticisms of the experts. Due to the pandemic process involved, the interviews with the teachers in the study were made via e-mail and the data obtained were analyzed by descriptive analysis method. According to the results of the research, when the opinions of the preschool teachers about the education information network were examined, it was stated that; the participation in the submitted studies was high, most of the students had connection problems while entering the system, the teachers were at a medium level in the use of information technologies and the content on the system was insufficient. Developing and enriching the content in the system, raising awareness of parents, facilitating the use of the system and solving technical problems were suggested by the participants.
\end{abstract}

COTUARA Journal. All rights reserved

Key words:

Education Information Network, pre-school edication, fatih project

\section{INTRODUCTION}

Preschool education covers the period between the ages of 0-6 that the individual spends from the day she was born to the day she entered the basic education institution. However, it is the development and education process, which is also called the period in which childhood development is completed and the personality takes shape, which has a significant impact on the individual's later life (Aral, Kandır \& Can Yaşar, 2001). It covers the education of children between 36 and 72 months who have not reached the age of starting primary school, but not compulsory (Poyraz, 2001).

The quality of education offered to students in this early childhood period is very important in terms of shaping the child's personality and preparing it for basic education. Therefore, it is obvious how important pre-school teachers who will give this education in the school environment are for students and society. Teachers who constantly improve themselves, who have a certain stance, who constantly benefit from developments while performing learning-teaching activities, who are constantly self-renewing, curious, loving to explore, have self-confidence, can cope with the difficulties they face, have an important share in the better upbringing of children. The 0-6 age range is a very important stage in children's lives in terms of individual development and education. In this effective phase, in which basic knowledge and skills are learned, a great deal of attention should be paid to education and no accidental expectations should be entered. For this reason, pre-school education should be given scientifically and systematically Children start learning quickly as soon as they open their eyes to the world. In preschool years, children are very sensitive to what is happening around them. During this period, children behave very active, curious, and skeptical like a research scientist. They associate the causes and consequences of the events they encounter by asking questions. The child is not as active in her life as in this period. The most important job is to learn. It questions all living and non-living objects around it and all the events it perceives and quickly appropriates it ( Kaçar \& Doğan, 2007 ) .

\footnotetext{
1 Ministry of Education, sevilay.sarisik@ogr.sakarya.edu.tr, orcid.org/0000-0001-6750-4949

2 Ministry of Education, salih.sarisik@ogr.sakarya.edu.tr, orcid.org/0000-0002-6506-2830
}

3 Ministry of Education, mfdclk $@$ hotmail.com, orcid.org/0000-0003-2279-6460 
The rapid development of technology in every field today has led to the provision of various opportunities, and a certain part of the different opportunities offered has been used in the field of education. Due to this use, there is an expectation that it will be developed to teach the use of technology in the education and training process (Cüre \& Özdener, 2008). Because the use of technology in educational activities provides individuals with equal opportunities in education by increasing the use of e-learning resources and enabling individuals to benefit from technological opportunities jointly, allowing individuals to collaborate (Golubev \& Testov, 2015). This approach will motivate students to be more successful in achieving their goals (Toprak \& Selçuklu, 2012). Technological learning tools provide permanence in learning situations by meeting the different learning expectations of individuals and thus support the learning - teaching process positively (Başarmak \& Mahiroğlu, 2015). The use of online learning tools motivates teachers in the teaching process and contributes to the permanent learning of individuals by enriching their educational activities. It has been observed that the mental and social skills of the students are positively affected by the use of technology in learning environments while using technology in learning-teaching activities (Çakıroğlu \& Taşkın, 2016; Şendağ \& Erol, 2015). It is very important for pre-school teachers to use technology effectively in the teaching process, to receive the necessary training and to develop themselves professionally on technological issues (Dong, 2018). In the current period when technological developments are very rapid, teachers are expected to follow technological developments in education closely and convey these technological developments in a meaningful way in order to be beneficial to students in their effective learning in order to provide education successfully and increase the development level of the society (Kaya \& Y1lmaz, 2013). In other words, the quality of education and the quality of the society are related to the success of teachers in using technology in educational environments.

With the use of information and technology in schools, it has been possible to prepare different methods and techniques in the teaching process, and thus some regulations and innovations have been developed in the development of the learning environment (Usta \& Korkmaz, 2010). Turkey in this area seen in many of the steps taken at the beginning of the Fatih Project and continued in Turkey and other countries and societies entering into people's lives and adversely affect Covidien-19 pandemic process of education comes Information Network. The education information network learning environment increases the diversity of the lesson activities teachers do with students with the e-contents it contains. While the use of visual, auditory and interactive course contents in the system increases the permanence of students 'learning, experiments and interactive applications also positively affect students' learning by doing and experiencing. In addition, it enables teachers and students to interact more effectively with each other through content sharing (Rutledge, 2011).

Examination of pre-school teachers' views on technology is important for a wide-ranging learning object warehouse such as the Education Informatics Network. As can be seen from the researches, the opinions of the teachers are very effective in the adoption of technology in educational environments. Adoption of technology will also increase teachers' use of information and technology in their learning activities and positively affect their views on technology. As can be seen from the studies of Asskar and Usluel (2002), the opinions of the teachers about the innovations in education have been very effective in order to be successful in the implementation phase. Examining the Covid-19 epidemic period and the use of educational information networks in preschool education institutions during this period increases the importance of the research. The opinions of teachers, who are the most effective users of the education information network platform, about this system are important in terms of the frequency of use, current status, adequacy and continuity of the system.

\section{Problem Statement}

What are the opinions of preschool teachers about the effect of using educational information network on education process?

\section{Purpose of the Research}

The aim of this study is to examine the effect of the use of Educational Informatics Network in pre-school education on the education process, according to the opinions of preschool teachers working in pre-school education institutions affiliated to the Ministry of National Education in Sapanca district of Sakarya province. 


\section{The Importance of Research}

Pre-school education period is one of the periods in which students' cognitive (mental) development is the fastest. Students have approaches such as researching, learning and discovering information in this period. Depending on these approaches, the child's environment has significant effects on her development and motivation. The most important of these environmental factors are teachers who follow the child's parents. Teachers working in pre-school education play an effective role in using developing technological facilities and equipment in classroom activities. Selected effective e-contents support the pre-school development areas and self-care skills of students. For pre-school students, teachers generally prioritize activity and game-based activities in order to reach the determined program and attainment indicators. Education Information Network is an e-learning platform that includes such activities and is useful for children. This learning platform includes storytelling, various games, visual activities, values education, information technology education, foreign language activities, drama, etc. It includes the e-contents needed in the pre-school period in many fields as a wide system.

Teachers need to constantly improve themselves in the periods after they start their profession. In particular, it can be said that teachers should constantly use and follow the skills of information and communication technologies in education. The level of pre-school teachers' knowledge of the education information network e-learning environment, the intervals of using the system and their attitudes towards this system make this study important. This study aims to determine the teachers' views on the effect of the use of Educational Informatics Network on the education process of preschool teachers during the covid-19 pandemic, which has affected the world. In the light of this purpose, it was aimed to evaluate and determine to what extent preschool teachers know the educational information network, the intervals of using the system and their attitudes towards this system with different views. With this importance, it is thought that the study will contribute to the field of pre-school education and education information network. In addition, it is predicted that the results of the study will contribute to the efficiency of the activities and studies of the education information network in the pre-school education period.

\section{METHOD}

In the study, semi-structured interview technique, one of the qualitative research methods (Yildırım \& Şimşek, 2008), which is defined as a qualitative research method that enables participants to express their personal experiences, perspective and thoughts on a subject, was used.

\section{Data Collection Tool}

Interview form was used as data collection tool in the study. During the preparation phase of the interview questions, the literature was examined and 6 open-ended questions that would express the relevant sub-problems in the best way were prepared by the researcher and written into the interview form. Openended research questions "provide the researcher with the opportunity to handle the phenomenon she wants to examine with a flexible and open-ended approach" (Yıldırım \& Şimşek, 2008).

In the study, the final form was given to the interview form, which was developed in order to determine the opinions of teachers on the effect of educational information network use in pre-school education, taking into account the gender, age, time spent in the profession and education status. There are six open-ended questions in the interview form.

\section{Data Analyses}

The data obtained from the interviews were analyzed by descriptive analysis method. Descriptive analysis method; a determined framework consists of steps such as transferring data to this framework, determining and interpreting the findings (Yıldırım \& Şimşek, 2008). For the analysis of the data, the thematic framework was determined by the researcher, within this scope, the data given by each researcher was coded, and the common themes were determined and coded by comparing the combined data.

The written texts formed as a result of the interviews were repeatedly examined, the data suitable for the purpose of the study were coded, and the themes that explain the encoded data at a general level were determined. The findings obtained are organized in tables. The teachers interviewed were coded starting from T1 to T19. In the interpretation of the findings, the opinions of the participants were included by quoting directly. 


\section{FINDINGS}

This section includes the findings of the research.

\section{Findings regarding the problem statement}

Various findings were obtained in line with the teachers' opinions about the effect of using educational information network in pre-school education on the educational process. These findings; The participation of pre-school students to the activities in the educational information network is not at a sufficient level, Internet and connection problems are usually experienced when communicating with the system, students have computer deficiency and internet connection problems while accessing the system, teachers' information technology usage levels are generally at medium level and the school in the system that the previous contents were insufficient and did not meet the gains.

\section{Findings related to sub-problems}

The findings regarding 6 sub-problems determined for the effect of using educational information network in pre-school education on the educational process are explained below.

Findings regarding the level of participation of teachers in the studies they send to students over the Education Information Network.

Education Information Network of Teachers Their views on their level of participation in the studies they sent to students through are presented below.

Table 1

Teachers' opinions about the level of participation in the studies they send to students through the Education Information Network

\begin{tabular}{|c|c|c|c|}
\hline Theme (Categories) & Codes & $\mathbf{N}$ & $\%$ \\
\hline $\begin{array}{c}\text { Students in the } \\
\text { education information }\end{array}$ & Not enough (T1,T2,T4,T5,T6,T7,T9,T10,T11,T12,T13,T14,T15,T17,T18,T19) & 16 & 84 \\
\hline $\begin{array}{l}\text { network participation in } \\
\text { studies }\end{array}$ & Enough $(\mathrm{T} 3, \mathrm{~T} 8, \mathrm{~T} 16)$ & 3 & 16 \\
\hline
\end{tabular}

When Table 1 is examined, it is seen that the opinions of teachers about the level of participation in the studies they send to students through the Education Information Network are not sufficient at the rate of $84 \%$. The other opinion was sufficient at $16 \%$. The exact quotations taken from the opinions of the teachers are presented below.

- " "I do not find their participation in the works I send to my students sufficient." (T5)

- " "Participation in the works I sent through the system is very good and sufficient." (T8)

Findings about the difficulties teachers encounter while communicating with their students over the Education Information Network.

Teachers' opinions about the difficulties they encounter while communicating with their students through the Education Information Network are presented below.

Table 2

Teachers' views on the difficulties they encounter while communicating with their students through the Education Information Network

\begin{tabular}{clcc}
\hline Theme (Categories) & Codes & $\mathbf{N}$ & $\mathbf{\%}$ \\
\hline Through the & Internet connection problem (T2,T7,T11,T12,T13,T14,T15,T16,T17,T18,T19) & 11 & 58 \\
education information & Young age (T3,T5,T6,T9,T10,T13,T16) & 7 & 37 \\
network with students & Lack of interest in families (T2,T3,T5,T7,T11,T19) & 6 & 31 \\
in communication & Computer skills (T2,T3,T4,T6,T8) & 5 & 26 \\
encountered difficulties & System is busy (T1,T10,T14,T15) & 4 & 21 \\
& Number of siblings going to school (T12,T17,T18) & 3 & 16 \\
\hline
\end{tabular}

When Table 2 is examined, it is seen that the opinions of teachers about the difficulties they encounter while communicating with their students through the Education Information Network are in the form of internet connection problems at the highest rate of $58 \%$. Other views are, in order, $37 \%$ being younger, $31 \%$ indifferent 
families, $26 \%$ computer skills, $21 \%$ intensive system and $16 \%$ school siblings. The exact quotations taken from the opinions of the teachers are presented below.

- "Unfortunately, some students either do not have internet infrastructure or have computers at home. However, some reasons can be said that some families care much about pre-school education." (T11)

- "Because they are young, they have to get help from their parents, but because the families do not show enough interest, we have communication problems."(T5)

- " "Parents not paying enough attention and some families have trouble connecting." (T7)

- "There are problems such as the internet connection, the inability of the child to use the computer effectively, and the family not being interested enough. "(T2)

- "Disconnected and not following the shared activities, work day by day." (T15)

- "Internet usage and technical difficulties generally occur. The number of siblings in the family negatively affects the pre-school students." (T18)

Findings about the difficulties faced by students in accessing the Education Information Network.

Teachers' views on the difficulties students encounter in accessing the Education Information Network are presented below.

Table 3

Teachers' views on the difficulties faced by their students in accessing the Education Information Network

\begin{tabular}{|c|c|c|c|}
\hline Theme (Categories) & Codes & $\mathbf{N}$ & $\%$ \\
\hline \multirow{7}{*}{$\begin{array}{l}\text { To the education } \\
\text { information network at reach } \\
\text { encountered difficulties }\end{array}$} & Internet connection problem (T8,T9,T10,T11,T12,T15,T16,T17,T18,T19) & 10 & 53 \\
\hline & Computer insufficiency (T11,T12,T13,T15,T16,T17,T18,T19) & 8 & 42 \\
\hline & Number of siblings (T5,T11,T12,T14,T19) & 5 & 26 \\
\hline & System is busy $(\mathrm{T} 1, \mathrm{~T} 3, \mathrm{~T} 4, \mathrm{~T} 7)$ & 4 & 21 \\
\hline & Indifference of families (T9,T14,T17) & 3 & 16 \\
\hline & Lack of information (T1,T6,T13) & 3 & 16 \\
\hline & Lack of attention $(\mathrm{T} 2, \mathrm{~T} 3)$ & 2 & 10 \\
\hline
\end{tabular}

When Table 3 is examined, it is seen that the opinions of teachers about the difficulties faced by their students in accessing the Education Information Network are mostly in the form of internet connection problems with a rate of $53 \%$. Other views, in turn, are computer insufficiency at $42 \%$, number of siblings at $26 \%$, intense system at $21 \%$, lack of interest and knowledge of families at $16 \%$ and lack of attention at $10 \%$. The exact quotations taken from the opinions of the teachers are presented below.

- "It is difficult for my students who do not have home internet but have limited mobile internet access." (T8)

- " "In general, the lack of internet infrastructure and internet, computers, the number of siblings." (T11)

- "Since there are several students in a family, older children are the priority. Preschool children are getting harder to access." (T5)

- "Due to the intensity, the system slows down and there is a problem in the connection". (T7)

- "Since most of the mothers and fathers in my class are teachers, I cannot reach children at a sufficient level because they are connected to their live lessons, their brothers or sisters are connected to the live lesson, preschool is not taken into consideration and they are ignored." (T14)

- "Not having enough information or the system being slow due to density makes entries difficult." (T1)

- "Öğrenciler küçük yaşta oldukları için dikkatlerini tam olarak veremiyorlar. Because students are young, they cannot pay attention properly. It restricts online media movements." (T2)

\section{Findings about the level of teachers' use of Information Technologies.}

Teachers' opinions about the level of Information Technologies usage are presented below.

Table 4

Teachers' views on the level of Information Technologies usage

\begin{tabular}{|c|c|c|c|}
\hline Theme (Categories) & Codes & $\mathbf{N}$ & $\%$ \\
\hline \multirow{3}{*}{$\begin{array}{c}\text { Your teachers } \\
\text { information technologies } \\
\text { usage level }\end{array}$} & Intermediate (T1,T2,T3,T5,T7,T9,T11,T12,T14,T16,T18) & 11 & 58 \\
\hline & Enough $(\mathrm{T} 4, \mathrm{~T} 8, \mathrm{~T} 15, \mathrm{~T} 17, \mathrm{~T} 19)$ & 5 & 26 \\
\hline & Not enough $(\mathrm{T} 6, \mathrm{~T} 10, \mathrm{~T} 13)$ & 3 & 16 \\
\hline
\end{tabular}


When Table 4 is examined, it is seen that the opinions of the teachers about their level of Information Technology usage are at the medium level at the rate of 58\%. Other opinions are, respectively, 26\% sufficient and $16 \%$ not sufficient. The exact quotations taken from the opinions of the teachers are presented below.

- " "I think I have a moderate use skill." (T7)

- "I do not find enough." (T4)

- "I am at the level of new learning." (T10)

Findings regarding the adequacy of the preschool course contents in the Education Information Network application and meeting the gains.

Teachers' opinions regarding the adequacy of the preschool course contents in the Education Information Network application and meeting the gains are presented below.

Table 5

Teachers' views on the adequacy of preschool course contents in the Education Information Network application and meeting the gains

\begin{tabular}{|c|c|c|c|}
\hline Theme (Categories) & Codes & $\mathbf{N}$ & $\%$ \\
\hline $\begin{array}{l}\text { Education Information } \\
\text { Network The adequacy of the } \\
\text { preschool content and the }\end{array}$ & Not enough (T1,T2,T3,T5,T6,T7,T8,T10,T11,T13,T14,T15,T17,T18,T19) & 15 & 79 \\
\hline status of meeting the gains & Enough $(\mathrm{T} 4, \mathrm{~T} 9, \mathrm{~T} 12, \mathrm{~T} 16)$ & 4 & 21 \\
\hline
\end{tabular}

When Table 5 is examined, it is seen that the opinions of the teachers about the adequacy of the preschool course contents within the Education Information Network application and meeting the gains are inadequate at the rate of $79 \%$. The other opinion is that it is sufficient by $21 \%$. The exact quotations taken from the opinions of the teachers are presented below.

- "Unfortunately, the content does not fully compensate for insufficient gains." (T2)

- " "I certainly do not find the contents to meet the gains and indicators." (T16)

Findings about the more efficient use of Education Information Network system in preschool curriculum.

Teachers' opinions about the more efficient use of the Education Information Network system in the preschool curriculum are presented below.

Table 6

Teachers' views on the more efficient use of the Education Information Network system in the preschool curriculum

\begin{tabular}{|c|c|c|c|}
\hline Theme (Categories) & Codes & $\mathbf{N}$ & $\%$ \\
\hline In the pre-school program & Content should be developed (T2,T3,T4,T5,T8,T11,T13,T14,T17,T18) & 10 & 52 \\
\hline of the Education Information & Parents should be informed (T1,T7,T9,T10,T15,T18,T19) & 7 & 37 \\
\hline Network use more efficiently & Usage should be made easy (T6,T12,T13,T15T16) & 5 & 26 \\
\hline Suggestions for & Solving the connection problem $(\mathrm{T} 13, \mathrm{~T} 17, \mathrm{~T} 18, \mathrm{~T} 19)$ & 4 & 21 \\
\hline
\end{tabular}

When Table 6 is examined, it is seen that the opinions of teachers about the efficient use of the Education Information Network system in the preschool curriculum are at most $52 \%$ as content should be developed and enriched. Other opinions are, in order, raising awareness of parents by $37 \%$, facilitating use by $26 \%$, and solving connection problems at $21 \%$. The exact quotations taken from the opinions of the teachers are presented below.

- "Digital content can be increased, online educational games etc. materials can be shared by teachers." (T2)

- "First of all, the importance of pre-school education should be adopted by families and students should be provided with sufficient equipment and awareness about conscious literacy." (T7)

- "Some activities can be made more understandable for children. Level suitability should be considered." (T12)

- "Providing technical facilities, enriching the contents and educating families on the subject. " (T18)

\section{RESULT AND DISCUSSION}

The results of this study, which was conducted in order to determine the teachers' views on the effect of educational information network use in pre-school education, on the educational process, and the results of the studies on the literature can be listed as follows: 
According to the opinions of the preschool teachers who participated in the study, it is revealed that the level of participation in the studies sent to the students through the system is not sufficient. Alabay (2015), in his study on the use of education information network by secondary school teachers and students, concluded that the rate of enrollment and use in the system is $6 \%$ in primary school, $44 \%$ in secondary school and $56 \%$ in high school. This result shows that as the education levels progress, the use of educational information network increases. It has been observed that participation in studies in the education information network at lower levels is not at a sufficient level. In her study on the effectiveness of distance education programs, Yadigar (2010) concluded that sufficient participation was not provided to the studies sent to students through distance education. Güvendi (2014), in her study on the use of educational information network, concluded that the participation of students in the studies in the system did not meet the expectations. These results support this research. According to the opinions of the preschool teachers who participated in the study, it was revealed that while teachers were communicating with students through the educational information network, students often had internet connection problems and their computer skills were inadequate due to their age. When the users' usage of educational informatics network was examined, it was seen that there were similar results to the research conducted when the literature was examined within the scope of difficulties encountered. In the study conducted by Güvendi (2014) in order to determine the frequency of use of online education and sharing sites offered to teachers by the Ministry of Education, it was concluded that technical problems arise from the internet connection infrastructure while teachers communicate with students through the system. In the study conducted by Türker and Ateş, Çerçi and Derman (2014) on the Turkish course videos in the education informatics network, it was concluded that the course contents originating from the internet connection were loaded into the system in a longer time than required. These results are similar to the research. According to the opinions of the pre-school teachers who participated in the study, it was concluded that students often had internet connection problems while accessing the educational information network system, they did not have computers, and they could not access because of the large number of siblings attending school. In the study conducted by Kana and Aydın (2017) with the aim of examining the opinions of middle school teachers and students about the education information network, they concluded that the biggest problem teachers encountered while accessing the system was due to connection. Güven (2016), in his study on the level of utilization of high school teachers from the educational information network project and their views on the project, concluded that teachers and students could not use the system efficiently due to problems arising from the internet connection and could not access the system whenever they wanted. These results support the study.

According to the opinions of the preschool teachers who participated in the study, it was concluded that their ability to use information technologies was at a medium level. In a study conducted by Daşdemir, Cengiz, Uzoğlu, and Bozdoğan (2012) with the aim of determining teachers 'behavior towards using computers, they stated that there were differences between teachers' use of computers in their depths, considering the branches they graduated from. In an application study by Turan and Haşit (2014) on the technology acceptance model and classroom teachers, it was determined that teachers created resistance to information technology tools and approached with prejudice, and it was concluded that they thought they could not use technology. These results are in parallel with the research. According to the opinions of the preschool teachers who participated in the study, it was concluded that the preschool course contents included in the education information network application were generally not at a sufficient level and did not meet the course outcomes. Altın and Kalelioğlu (2015) in their study examining student and teacher views on Fatih project; They stated that the education information network site is not appropriate for their age, their teachers should receive training on the use of technology, technical support does not provide timely assistance and the content is insufficient. In an evaluation made by Ekici and Yilmaz (2013) on the Fatih project, it was concluded that the content included in the educational informatics network was insufficient. Kurt (2013), in her study on the evaluation of the pilot implementation process of the Fatih project, reported that the content at different grade levels did not match the gains. Güvendi (2014), in her research on determining the frequency of use of online education and sharing sites offered to teachers by the Ministry of National Education, concluded that the contents in the education informatics network were insufficient. Karatekin, Elvan, and Öztürk (2015), in their study examining the opinions of social studies and classroom teachers about the Fatih Project, found that the content of the course was not compatible with the outcomes, so it was necessary to examine the content of the curriculum while preparing. These findings support the study. 
According to the opinions of the preschool teachers who participated in the study about the more efficient use of the Education Information Network in the preschool curriculum, the most emphasized part is the enrichment and development of the contents. In addition, they think that it is necessary to raise the awareness of parents, to eliminate connection problems and to facilitate the use of the system. Demircioğlu and Yadigaroğlu (2014) made suggestions for the enrichment and improvement of the content of the education informatics network of the teachers participating in the study in their study, in which they examined the opinions of chemistry teachers regarding the conqueror project. In the study conducted by Tüysüz and Çümen (2016) by taking the opinions of middle school students regarding the education information network course website, the students stated that the system should be added with more games, puzzles and visuals, and more fun and remarkable subject content. In the study conducted by Türker and Güven (2016) on the level of benefiting from the education information network project of high school teachers and their opinions about the project, it was suggested that the content in the system should be constantly updated and seminars should be organized to introduce the education information network to all teachers and students in Turkey.

Based on the results of the research, the suggestions made to bring the use of educational information network in pre-school education to the expected level are as follows; It appears that pre-school teachers need in-service training on the use of Fatih Project, the use of educational information network and the use of Information Technologies. In order to increase the frequency of using educational information network, the technical connection problems of teachers and students should be resolved. It will be effective to develop the contents of pre-school education in the education information network, to add activities related to the gains, to increase the quality, to enrich and to prepare activities that encourage using the system. It will be important to include pre-school teachers' curricula about the effective use of Information Technologies and educational information network, as well as e-content production and development while studying at the faculty. Particularly, parents with children in pre-school period can be trained on the use of information technologies. We can facilitate the entrance of the system by directing with visuals at the entrance of the education information network system. In this study, it was examined only by filling the interview form. In future studies, it can be contributed to the literature with more comprehensive studies by using techniques such as questionnaire application and observation in addition to the interview form. This research was conducted only with preschool teachers. Similar studies can be conducted with other branch teachers working in different education levels such as primary school, middle school and high school on the use of education information network. In this study, it was determined that the contents in the education information network are insufficient. Studies can be conducted to investigate the reasons for this situation in detail. In our study on the use of education information network in pre-school education, only pre-school teachers constitute our study group. In similar studies, preschool administrators and parents can be added to the working group.

\section{REFERENCES}

Aktepe, V. (2011). Sınıf öğretmenlerinin derslerinde bilgisayarı kullanımına ilişkin görüşleri. Ahi Evran Üniversitesi Ĕ̆itim Fakültesi Dergisi, 12(3), 75-92.

Alkan, C. (2011). Eğitim Teknolojisi (8. Basım). Anı.

Altın, H. M. \& Kalelioğlu, F. (2015). FATİH Projesi ile ilgili öğrenci ve öğretmen görüşleri. Başkent University Journal of Education, 2(1).

Aral, N. (2003). Okul öncesi eğitim I. Ya-Pa Yayınları.

Arslan, Z. (2016). Ĕğitim bilişim ağındaki matematik dersi içeriğgine ilişkin öğretmen görüşleri: Trabzon İli Örneğgi. Yüksek Lisans Tezi, Gazi Üniversitesi Eğitim Bilimleri Enstitüsü. Ankara

Ateş, M., Çerçi, A. \& Derman, S. (2014). Eğitim bilişim ağında yer alan Türkçe dersi videoları üzerine bir inceleme. Sakarya University Journal of Education, 5/3, 105- 117.

Çevik, H. \& Duman, T. (2018). Analyzing the effects of e-learning on science education. International Journal of Instruction, 11(1), 345-362.

Daşdemir, İ., Cengiz, E., Uzoğlu, M. \& Bozdoğan, A. E. (2012). Tablet bilgisayarların fen ve teknoloji derslerinde kullanılmasıyla ilgili fen ve teknoloji öğretmenlerinin görüşlerinin incelenmesi. Mustafa Kemal Üniversitesi Sosyal Bilimler Enstitüsü Dergisi, 9(20). 
Demircioğlu, G. \& Yadigaroğlu, M. (2014). Kimya öğretmenlerinin Fatih projesine ilişkin görüşleri. Eğitim ve Öğretim Araştırmaları Dergisi, 3(2), 302-310.

Ekici, S. \& Yılmaz, B. (2013). FATİH projesi üzerine bir değerlendirme. Türk Kütüphaneciliği, 27(2), 317-339.

Ertürk, S. (1982). Eğitimde Program Geliştirme (4. Baskı). Meteksan.

Eryılmaz, S. \& Salman, Ş. (2014). Fatih Projesi kapsamında yer alan öğretmen ve öğrencilerin projeden beklentileri ve bilişim teknolojileri kullanımına karşı algıları. Elektronik Mesleki Gelişim ve Araştırma Dergisi, 2(1). 46-63.

Fidan, N. K., Erbasan, Ö. \& Kolsuz, S. (2016). Sınıf öğretmenlerinin eğitim bilişim ağı'ndan (EBA) yararlanmaya ilişkin görüşleri. Journal of International Social Research, 9(45), 626-637.

Güntekin, H. (2015). Etkileşimli tahta ekran görüntülerinin resim ve video formatında paylaşımının öğrenenler açısından incelenmesi (Yüksek Lisans Tezi).

Güvendi, G. M. (2014). MEB'nın öğretmenlere sunmuş olduğu çevrimiçi eğitim ve paylaşım sitelerinin öğretmenlerce kullanım sıklı̆ı̆ıı belirlenmesi: Eğitim Bilişim Ağı (EBA) Örneği. Yüksek Lisans Tezi.Sakarya Üniversitesi.

Kana, F. \& Aydın, V. (2017). Ortaokul öğretmenleri ve öğrencilerinin eğitim bilişim ağı hakkında görüşleri. Journal Of Social And Humanities Sciences Research (Jshsr), Vol:4, Issue:13, 1494-1504.

Karabacak, N. (2015). Türk eğitim sistemindeki Fatih projesinin CIPP modeline göre incelenmesi. Mersin Üniversitesi Ĕ̆itim Fakültesi Dergisi, 11(3), 700- 719.

Karatekin, K., Elvan, Ö. \& Öztürk, D. (2015). Sosyal bilgiler ve sınıf öğretmenlerinin Fatih Projesi hakkındaki düşünceleri. Uluslararası Avrasya Sosyal Bilimler Dergisi, 6(18), 81- 114.

Kartal, M. (2017). Sosyal bilgiler öğretmenlerinin eğitim bilişim ağı (EBA) hakkındaki görüşleri (Yüksek Lisans Tezi).

Keleş, E. \& Turan, E. (2015). Öğretmenlerin Fırsatları Arttırma ve Teknolojiyi İyileştirme Hareketi (FATİH) projesi hakkındaki görüşleri. Turkish Journal of Education, 4(2).

Kurt, A. (2013). Fatih projesinin pilot uygulama sürecinin değerlendirilmesi: Öğretmen görüşleri. Journal of Instructional Technologies \& Teacher Education, 2(1), 1-23.

Kurtdede Fidan, N., Erbasan, Ö. \& Kolsuz S. (2016). Sınıf öğretmenlerinin eğitim bilişim ağından (EBA) yararlanmaya ilişkin görüşleri. Uluslararası Sosyal Araştırmalar Dergisi, 45, 627-636.

Milli Eğitim Bakanlığı (MEB). (2012). FATï projesi web sayfası. 17 Nisan 2015 tarihinde http://fatihprojesi.meb.gov.tr/tr/index.php sayfasından erişilmiştir.

Özkan, A. \& Deniz, D. (2014). Orta öğretimde görev yapan öğretmenlerin FATïH Projesi'ne ilişkin görüşleri. Ege Eğitim Dergisi, 15(1), 161-175.

Pala, F.K., Arslan, H. \& Özdinç, F. (2017). Eğitim bilişim ağı web sitesinin otantik görevleri, IHEAD, 2(1), 2438.

Poyraz, H. (2001). Okul öncesi eğitimin ilke ve yöntemleri. Ders notları

Tanrıkulu, F. (2017). EBA'nın Türkçe dersi öğrenme alanlarını karşılama yeterliliğine yönelik öğretmen görüşleri. Ana Dili Ĕ̆itimi Dergisi, 5(3).395-416.

Tutar, M. (2015). Eğitim Bilişim A $\breve{g ̆}_{\imath}$ (Eba) Sitesine Yönelik Olarak Öğretmenlerin Görüşlerinin Değgerlendirilmesi, Yayımlanmamış Yüksek Lisans Tezi. Karadeniz Teknik Üniversitesi Eğitim Bilimleri Enstitüsü, Trabzon.

Turan, B. \& Haşit, G. (2014). Teknoloji kabul modeli ve sınıf öğretmenleri üzerinde bir uygulama. Uluslararası Alanya İşletme Fakültesi Dergisi, 6(1), 109-119.

Türker, A. \& Güven, C. (2016). Lise öğretmenlerinin eğitim bilişim ağı (EBA) projesinden yararlanma düzeyleri ve proje ile ilgili görüşleri. Ĕ̆itim ve Öğretim Araştırmaları Dergisi, 5/1, 244-254.

Tüysüz, C. \& Çümen, V. (2016). EBA ders web sitesine ilişkin ortaokul öğrencilerinin görüşleri. Uşak Üniversitesi Sosyal Bilimler Dergisi, 2016 9/3, 278-296. 
Vural, R.A. \& Ceylan, V.K. (2014). Fatih Projesi eğitimde teknoloji kullanım kursunun öğretmen görüşlerine göre değerlendirilmesi. Türkiye'de İnternet Konferansı, Yaşar Üniversitesi, İzmir

Yıldırım, A. \& Şimşek, H. (2008). Sosyal bilimlerde nitel araştırma yöntemleri: Seçkin Yayıncılık.

2023 Eğitim Vizyonu. (2018). http: // 2023 vizyonu .meb.gov.tr /doc/ 2023 _ egitım _ vizyonu.pdf 